\title{
薬学のコミュニケーション教育におけるフィジカルフィギアの活用
}

\author{
大鳥 徹, 村上 悦子, 松山賢 治*
}

\section{Practical Use of the Physical Assessment Model in Communication Training of Pharmaceutical Sciences}

\author{
Toru Otori, Etsuko Murakami, and Kenji Matsuyama* \\ Faculty of Pharmacy, Kinki University; 3-4-1 Kowakae, Higashiosaka, Osaka 577-8502, Japan.
}

(Received May 13, 2011; Accepted November 28, 2011; Published online December 5, 2011)

Since 2005, the Japanese pharmacy education program has changed to a six year-system from a four year-system with the aim to help students obtain a higher level of clinical knowledge and skill regarding humanity and morality. Under the new pharmacy education system, the correct assessment of vital signs is observed in pharmacy practice so that pharmacists can sell "over the counter drugs (OTC)" safely. From this point of view, we started a pharmacy practice that recognizes a series of vital signs, i.e., blood pulse, blood pressure, respiratory sound, and electrocardiogram, using a physical figure subjecting to 4 th-year students $(n=142)$. After the practice, a questionnaire was conducted in order to assess the satisfaction of the practice. The results suggested that students could successfully learn physical assessment by using physical figures (ratios more than grade $4: 60 \%$ ). Students could also evaluate the necessity of physical assessment (ratios more than grade 4: 70\%), suggesting the practice of using physical figures was accepted by most students.

Key words_— vital sign; physical figure; physical assessment

緒言

高齢化社会の進展に伴い医療費削減は喫緊の課題 であり，この観点からリフィル処方箋導入の動きが 始まっている.リフィル処方箋とは 1 回処方箋が発 行された後は, 薬局で繰り返し処方薬を受け取れる システムである。このシステムで薬剤師は，患者の バイタルサインを把握し異常があれば受診勧告する など重要な役割を担っており，薬学教育でフィジカ ルフィギアを用いたバイタルサインの学習は重要な ものとなってきている. また，OTC の適正販売に おいても患者の病態を的確に評価するためバイタル サインの把握は以前にも増して必要性が高くなって きている.

6 年制薬学教育における目的の 1 つとして患者や 医療従事者とのコミュニケーション能力の涵養が挙 げられている。このような状況下，薬系大学におい て臨床現場を再現した実習室の整備，模擬患者 (SP; Standardized Patient/Simulated Patient) ${ }^{1-3)}$ や

近畿大学薬学部

*e-mail: matsuyama@phar.kindai.ac.jp
フィジカルシミュレータを用いた教育 ${ }^{4)}$ が行われて いる．従来のフィジカルフィギアを用いた実習は， 人の代替として医学教育の中から発生しており, 薬 学教育への応用はいまだ手探りの状況である.

近畿大学薬学部（以後, 本学と略す）では実務実 習事前学習の一環として, 不整脈と薬物治療のシナ リオを 2 課題作成し，スモールグループディスカッ ション（SGD）を介して，患者への服薬指導のア プローチから締めくくりの言葉がけまでをロールプ レイさせる実習を行った。この間，問題のある処方 に対する医師への疑義紹介と推奨薬の提案を行うな ぞ医療における薬剤師の基本的態度・技能を習得さ せる実習も組み込まれている。本実習の特徵は各シ ナリオの不整脈をフィジカルフィギアで再現し，教 員が操作することで, 学生が提案した薬物治療によ り心電図はどう変化するかをビジュアルに体験させ ることを通じて, 薬物の適正使用と心電図変化やバ イタルサインの変化を総合的に学習させることにあ る. 最後に教員による不整脈の総括講義がなされ， 対面授業で教えるのが困難な不整脈と薬物治療も, コミュニケーション実習の一環に組み込まれた総合 
的な薬物治療の実習として統合できた．本研究の目 的は，コミュニケーション実習の中でフィジカルフ イギアの有効な活用法として, バイタルサインの実 習から始まり，不整脈の心電図提示，不整脈の薬物 治療まで止揚した実習形態の紹介と評価であり，実 習後に行ったアンケート結果から教育効果に関する 興味深い知見を得たので報告する。

\section{方法}

\section{1. 実務実習事前学習 対象は薬学部医療薬学} 科 4 年生（6 年制薬学教育における 4 年次） 142 名 で, 1 グループ 22-24 名の 6 グループに分け, 平成 22 年 9 月 13 日から 12 月 9 日に 4 日間を 1 クール とする実務実習事前学習を行った. 1 日当たりの実 習時間は, 360 分 (4 限分) で行った.

フィジカルフィギアを用いたコミュニケーション 実習（以下，本実習と略す）に関しては，1グルー プをさらに 5-6 名からなる 4 サブグループに分け行 つた. 課題症例として Fig. 1, 2 に示す心房粗動患 者とジゴキシン中毒患者の症例を準備し PBL 形式 の実習を行った。

学生は，まず，各班でスモールグループディスカ ッション（以後，SGD と略す）を行い, 疑問点, 問題点を抽出し，これに沿って薬学的介入・管理に よる正しい薬物治療をまとめその結果をプレゼン テーションする (Fig. 3).

総括講義の後, 1 時間程度フィジカルフィギアを 用いて，ジゴキシン中毒と心房粗動患者の心電図を 開示し，学生が提案した薬物治療を行った場合の改 善効果を心電図上で示し, 薬物の適正使用の必要性 を学生に学ばせる。この実習により，不整脈治療に おける抗不整脈薬やジゴキシンの適正使用を自ら学 び薬学的知識を臨床適用する能力を身につけさせる。

2. フィジカルフィギア 本実習では，フィジ

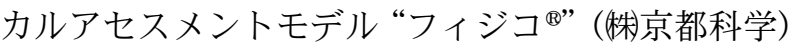
と心臟病診察バイタルサインシミュレータ“イチ ローツ”(侏京都科学) の2 種を用いた。

フィジカルアセスメントモデル “フィジコ” は, バイタルサインに関する実習で使用し，血圧測定， 脈拍，心音，呼吸音，腸音及び心電図の測定方法を 学ばせる装置である。このフィギアの特徴は，個別 手技の総合技術を高めるため, 代表的な 12 人の疾 患患者（心筋梗塞，心不全など）の選択が可能なこ

\section{実務実習事前学習課題}

患者：近畿 正夫 (正子) さ九 63 歳 男性 (女性)

ここは小若江病院循環器内科病棟で、あなたは実務実習の学生です。 近畿さんは、昨日、頻脈で精密検査のために入院。これから近畿さんの初回面談を行いま す。下記の項目 の)について、患者さんへの対応を行ってください。処方内に不都合があ る場合には、それを指摘しなさい。

病室への入室と患者への声かけ（机のわきからベッドサイドに出て行ってください。）

- 既往歴、持参楽、アレルギー歴、薬による副作用歴、嗜好などの患者情報の収集(必要 に応じ患者背景なども聞き取りしてよい

・ 終了のあいさつ

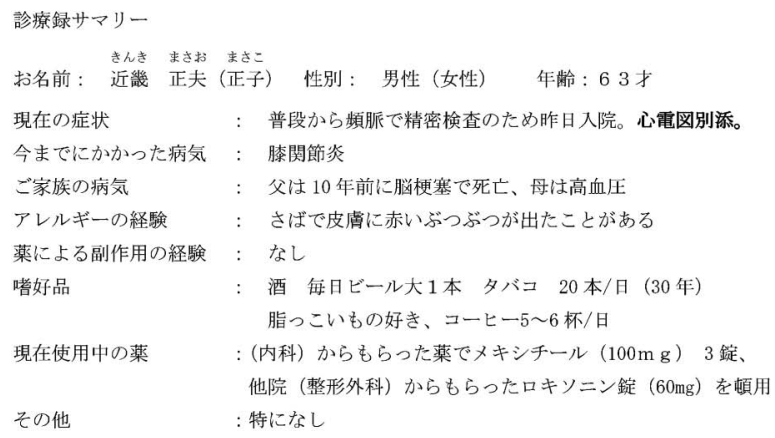

Fig. 1. Case Study for Atrial Flutter

\section{実務実習事前学習課題}

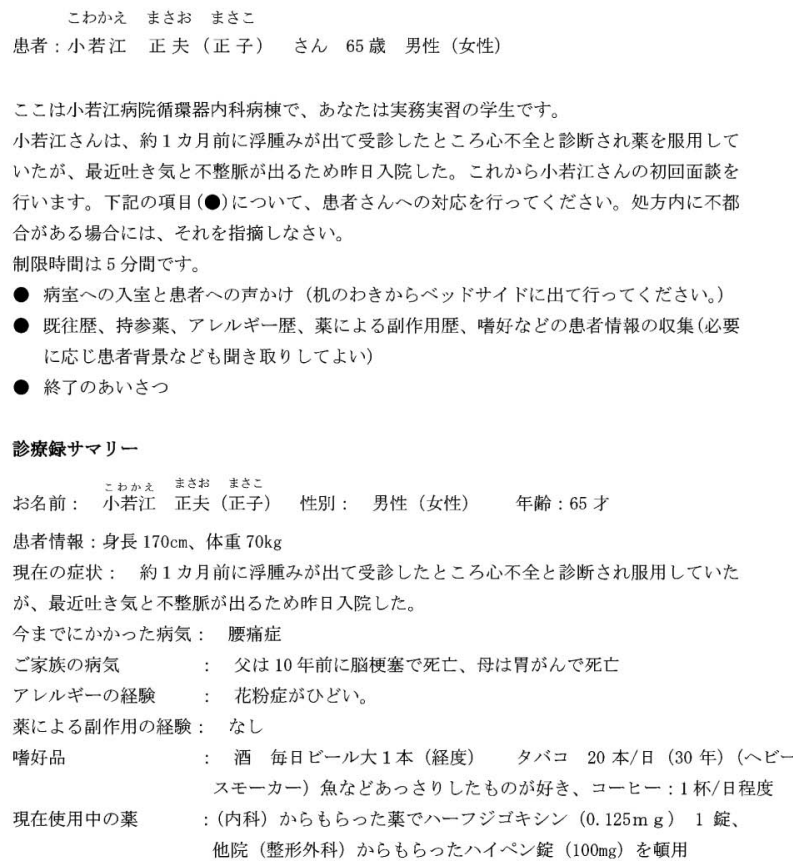

Fig. 2. Case Study for Digoxin Intoxication

とである。さらに，任意設定における各種疾患患者 作成や血圧測定，聴診，脈拍測定，心電図測定など 個別手技モードによりバイタルサイン測定技術の向 


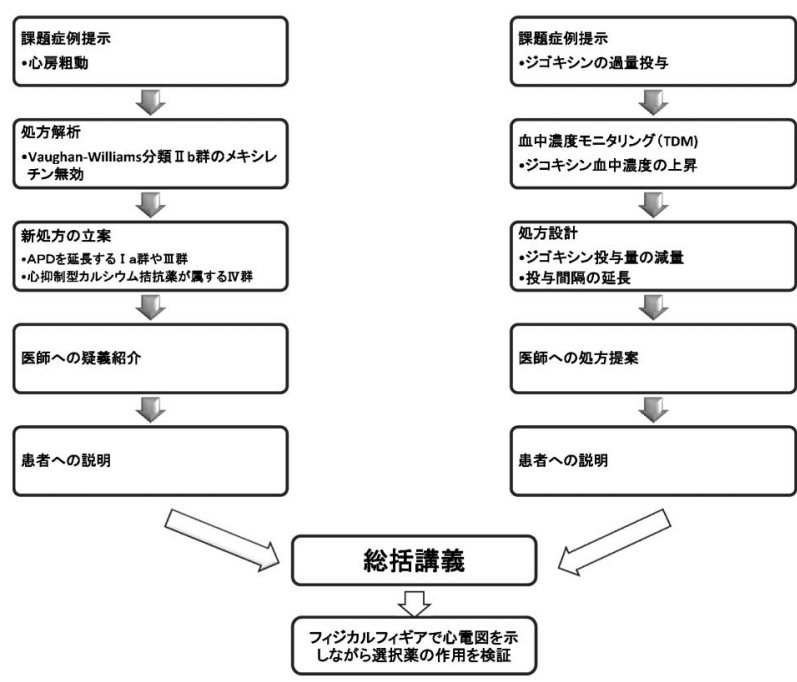

Fig. 3. Training Chart for Studying Electrocardiogram

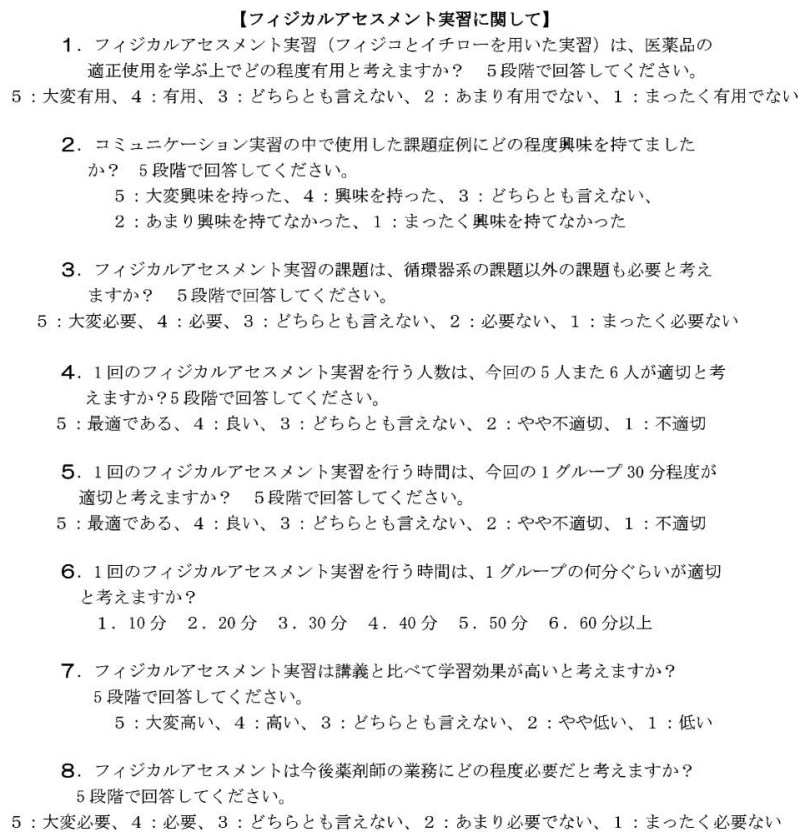

Fig. 4. Questionnaire

上が可能である. ${ }^{4)}$

心臓病診察バイタルサインシミュレータ“イチ ロー®”、，胸部診察に特化しており，心疾患 88 症 例，肺疾患 36 症例について心電図・心音，呼吸音 を限りなく実際の症例に近い形で再現することがで きる. ${ }^{4)}$

3. フィジカルフィギアを用いたコミュニケーシ ヨン実習の評価実習終了後, 2 グループ毎に本 実習に関するアンケート調査を行った（Fig. 4). アンケートは，8つの設問を 5 段階評価と 6 肢 1 択
により記名形式で実施した。

\section{結 果·考 察}

本学では，2009年より実務実習事前学習におけ る本実習で臨床現場をシミュレートした PBL 教育 を開始している，本実習は，患者に薬物療法に関す る情報を分かり易く説明するコミュニケーション能 力を身につけさせると同時に，フィジカルアセスメ ントなどから得た臨床情報と学生がこれまで蓄積し た知識を薬物療法に反映する能力を醸成することを 目標としている.

薬剤師が行うフィジカルアセスメントは, 現時点 で医師法 17 条に抵触する恐れがあり解決すべき問 題もある．しかし，日本病院薬剤師会は，今後の薬 剂師の業務展開において, 薬剤師が病棟に常駐し, カンファレンス参加，カルテや看護日誌の閲覧な ど，間接的な情報収集に留まらず，必要に応じて触 診や聴診といったフィジカルアセスメントを行い, 患者の状態の経過観察による直接的な患者情報の収

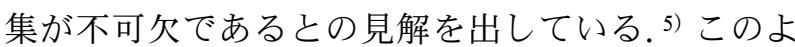
うな薬剤師業務に求められる新たなニーズを踏ま え，筆者らは本実習において，フィジカルフィギュ アで上室性不整脈患者症例とジゴキシンの過量投与 症例を再現し，不整脈の発生メカニズムとそれぞれ の症例に関する知識を深め, 抗不整脈薬の選択とジ ゴキシンの投与計画を行う実習を試みた。

本実習に関する学生アンケートは，回収率 $99 \%$ で以下のような結果となった（Fig. 5).

設問 1.「フィジカルアセスメント実習（フィジ コとイチローを用いた実習）は，医薬品の適正使用 を学ぶ上でどの程度有用と考えますか?」（以後, 「フィジカルアセスメント」実習と略す）で 4 （有 用）以上の評価をした学生が $66 \%$ であったことや, 設問 7.「フィジカルアセスメント実習は講義と比 べて学習効果が高いと考えますか?」（以後，「学習 効果」と略す）に関して 4（高い）以上の評価をし た学生が 69\%であったことからも，本実習中に薬 物の適正使用を学ぶことは学生にポジティブな効果 を与えたものと考える.さらに，心房粗動にメキシ レチンが処方されている症例で, SGD により学生 がジゴキシンやべラパミルなどへの処方変更を提案 した場合，教員がフィジカルフィギアを操作して対 応する心電図を画面に出す実習を行った。これは, 


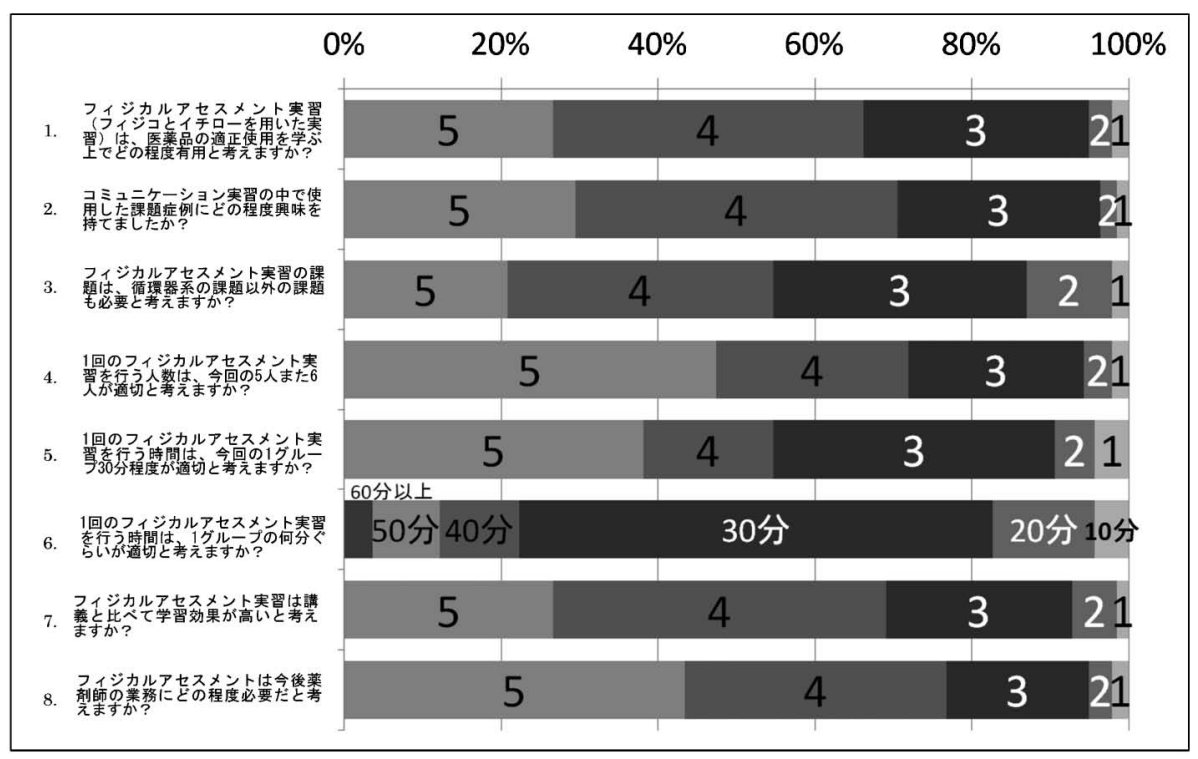

Fig. 5. Results of Questionnaire as to Degree of Satisfaction

あたかも実際に患者に対して薬を投与したような臨 場感を持たせ，本実習の工夫した点と言える。実際 に, 本実習を行う学生は, 心電図, 血圧, 心拍数な どのバイタルサインの確認やディスカッションをこ れまでにないほど真剣に行い, 新たな薬物治療計画 の立案に集中して取り組んでいたように見えた.

フィジカルフィギアを用いて課題症例の病態を再 現し心電図, 心音, 血圧などのチェックを行い薬の 効果を実際に確認したことにより実習に対する理解 度がさらに増したと考えられる. 現にアンケートの 設問 8.「フィジカルアセスメントは今後薬剤師の 業務にどの程度必要だと考えますか?」（以後,「薬 剤師業務」と略す) の結果において 4 (必要) 以上 の評価をした学生が 76\%であったことは, チーム 医療の中で薬の専門家たる薬剂師が, 添付文書の使 用上の注意事項を考慮し, 副作用の予測又は回避に 必要な「血圧, 脈拍, 体温測定や聴診, 視診などの フィジカルアセスメント」を行うことが非常に重要 な任務であることを十分に理解し得たためと考える (Fig. 5).

しかし, 実際に薬剤師による「血圧, 脈拍, 体温 測定や聴診, 視診などのフィジカルアセスメント」 が実施されている施設は全国でわずか 143 病院 $(4.5 \%)^{5)}$ に留まり, 薬剤師教育における, フィジカ ルアセスメント教育の充実が望まれる.

ところで, 今回フィジカルフィギアを用いた実習 を 1グループ 5-6 人で実施したが, アンケートの設
問 4.「1 回のフィジカルアセスメント実習を行う人 数は, 今回の 5 人また 6 人が適切と考えますか?」 (以後,「グループ人数」と略す) の結果において 4 （良い）以上の評価をした学生が $71 \%$ あっったこと や, 1 回の実習を行うグループの人数は 5-6 人程度 の少人数が望ましいことが分かった。 また，アン ケートの設問 5.「1 回のフィジカルアセスメント実 習を行う時間は, 今回の 1 グループ 30 分程度が適 切と考えますか?」(以後,「実習時間」と略す) （フィジカルフィギア実習約 60 分）の結果において 4 (良い) 以上の評価をした学生が 54\%であったこ とや，設問 6.「1 回のフィジカルアセスメント実習 を行う時間は, 1 グループの何分ぐらいが適切と考 えますか? 1.10 分 2.20 分 3.30 分 4.40 分 5.50 分 6.60 分以上」 (以後, 「実習時間選 択」と略す）の結果において 3 (30 分）の評価をし た学生が $60 \%$ でったことからも, 60 分はやや長 すぎで, 要点を簡潔に 30 分以内で行うことが望ま しいようである. また，シナリオの作成において は, アンケートの設問 2.「コミュニケーション実 習の中で使用した課題症例にどの程度興味を持てま したか？５段階で回答してください」（以後，「課 題への興味」と略す）の結果において 4（興味を持 った）以上の評価をした学生が 70\%であったこと や, アンケートの設問 3.「フィジカルアセスメン 卜実習の課題は, 循環器系の課題以外の課題も必要 と考えますか?」(以後, 「循環器系課題」と略す) 
の結果において 4（良い）以上の評価をした学生が 54\%であったことからも,“フィジコ” と“イチロー ${ }^{\circledR} ”$ を用いて行うフィジカルアセスメントの課題として 今回の循環器系の課題は妥当な分野であり，学生に 受け入れられたと考える．今後，さらに学生の希望 する分野などを調査し，学生のニーズに応じたシナ リオを作成したいと考えている（Fig. 5). ${ }^{6}$

上室性不整脈患者症例において学生は SGD で, 心臓における自律神経系の働き，心臓の刺激伝導 系，抗不整脈薬の分類などに関する知識の収集を成 書やインターネットで行う。その結果，提示された 課題症例に対する薬剤師の正しい対応をディスカッ ションで決定し，新たな薬物治療計画を提案するこ とが可能となった．Figure 6 に心電図の解析，治療 薬選択の手順が筆者の行つたミ二講義の内容に従い 簡潔明瞭に記載されていた学生レポートを示す.

学生は，与えられた課題症例の心電図パターンか ら患者の不整脈は，心房粗動との判断を行い提示症 例に示されたメキシレチンは無効であることを全 員が認識した。学生は新たな治療薬候補として Vaughan-Williams 分類 I a 群やIII群，IV群又はジ ゴキシンを正しく挙げてきた。 中でも，最も副作用 などの少ないIV群のベラパミルや洞遮断薬のジゴキ シンを選択するケースが多く，これはグループ学習 の成果として特筆できよう。学生は添付文書などの 医薬品情報資料から自らで最も適切と考える処方提
示を行っており，PBLにおいて自ら学ぶことが対 面型講義と並んで非常に有効であることを認識させ られた。

学生による発表の後, 教員による総括講義を行っ た。ここでは，心房粗動と細動の心電図上の相違， また心房粗動にケント束など副伝導路が存在する場 合 WPW 症候群を惹起し易くなることを説明し， 特にデルタ波を伴うWide QRS の心電図を示す場 合ベラパミル，ジゴキシンは刺激伝達系の主伝導路 を抑制し，刺激を副伝導路へ誘導することにより擬 性心室頻拍を惹起することを説明した（Fig. 7).

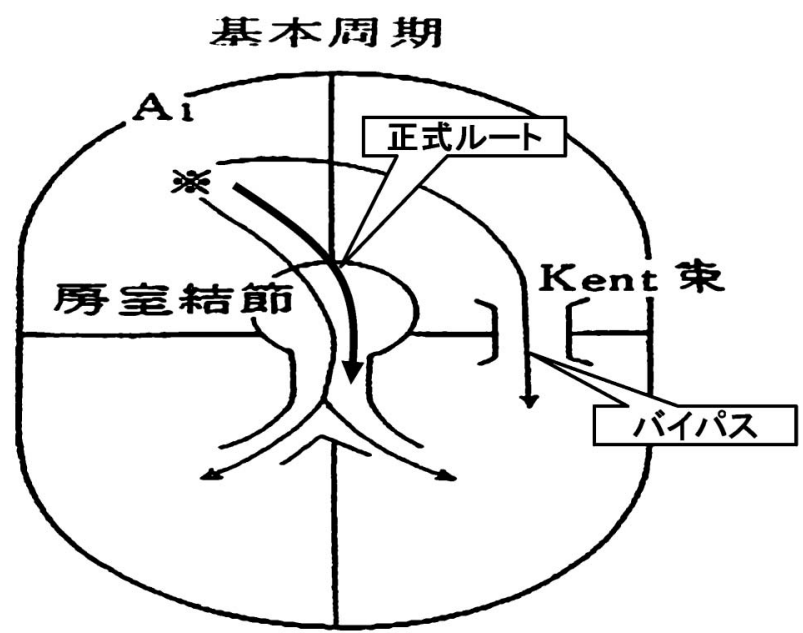

Fig. 7. Schema of Heart Stimulation Pathway in the Case of Kent's Bundle

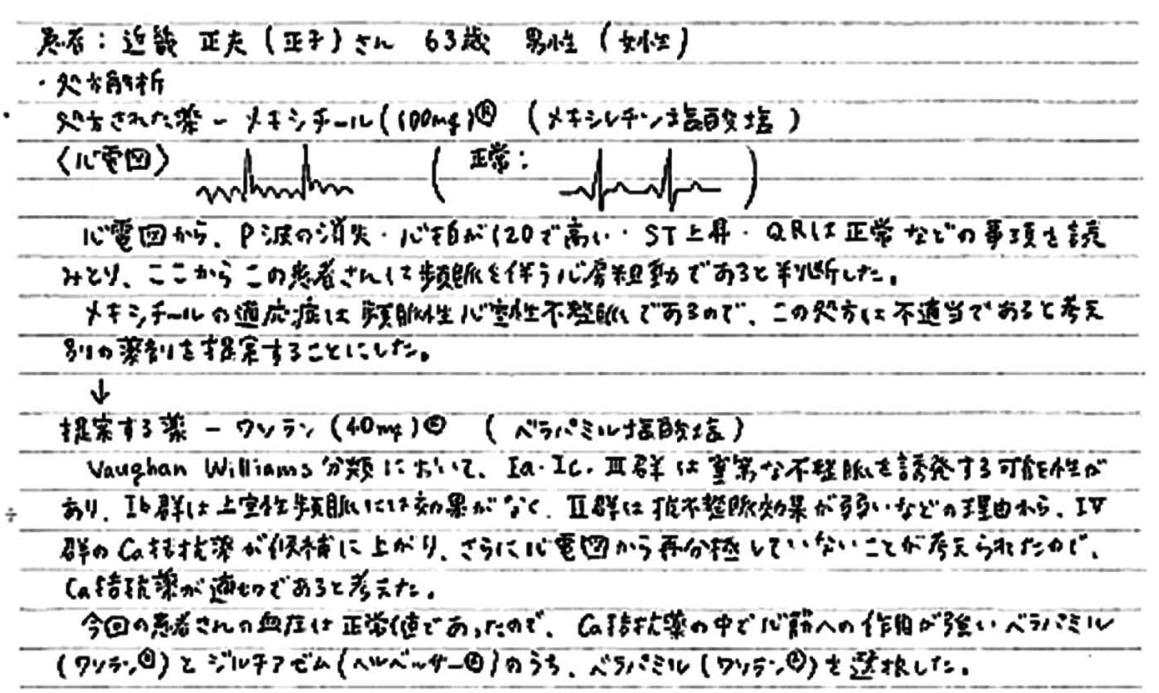

Fig. 6. Example for the Report from Students 


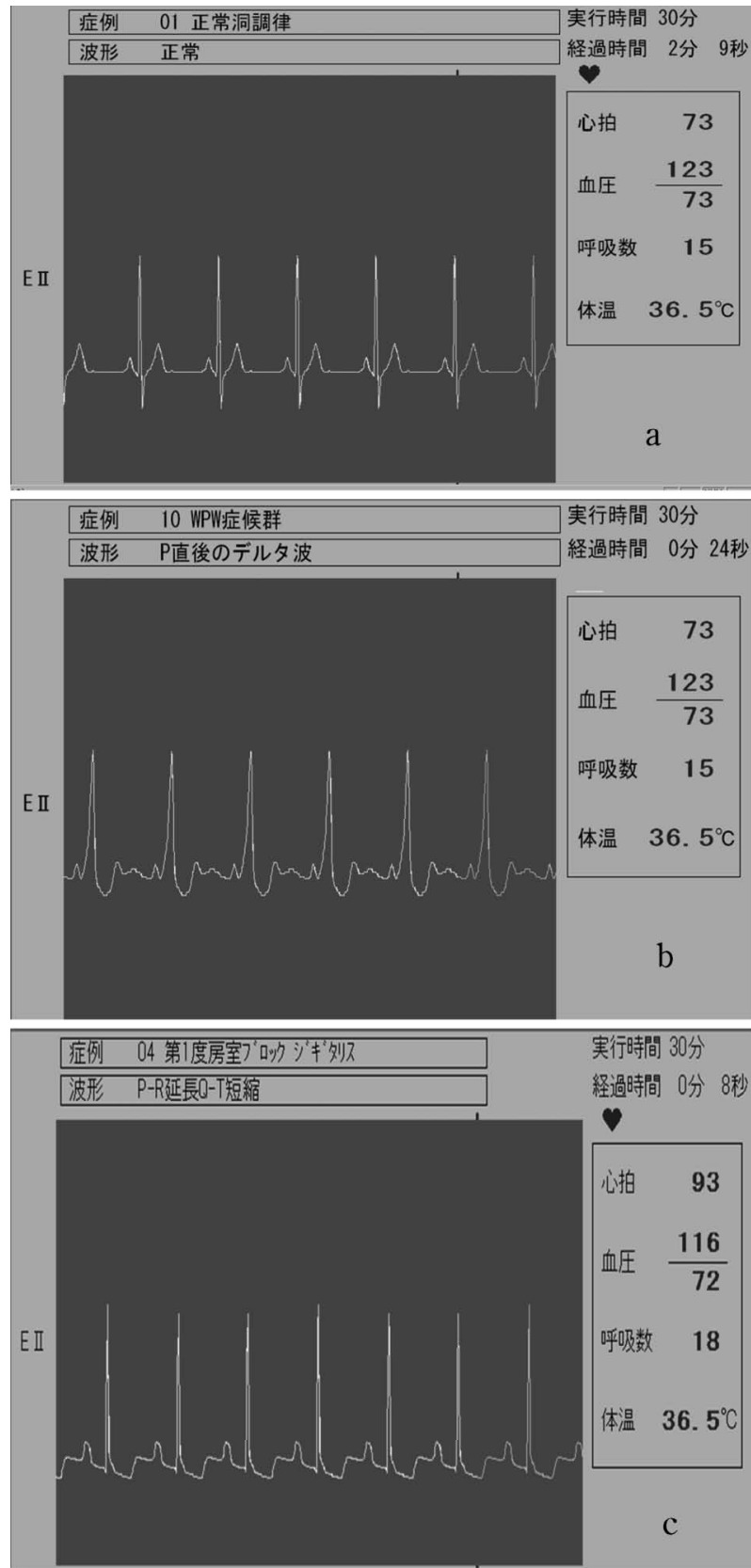

Fig. 8. Electrocardiogram

a: Normal case, b: WPW syndrome with delta wave (Wide QRS), c: Digoxin in toxication with ST drop.

説明後，フィジカルフィギアを用いて WPW 症候 群におけるデル夕波を伴うWide QRS の心電図を 見せて本実習を締めくくった（Fig. 8).
ジゴキシンの過量投与症例においては，心電図上 のST 波の盆状降下を見せ (Fig. 8)，その際の副作 用対策や TDMによる薬物投与計画案を提案させた.

以上のごとく学生の実習終了アンケートにおいて すべての項目において比較的高い評価を受けていた ことから，今回筆者らが報告したフィジカルフィギ アを用いたコミュニケーション実習は，医師への疑 義照会に関するコミュニケーション事例も含まれ医 療現場における薬剤師業務を一連の流れに沿ってリ アルに再現し，臨床現場をシミュレートした PBL 教育を行うことができたと考える，今後，われわれ は今回の実習で得たアンケート結果を基に実習内容 の検討と改善を行い，より教育効果の高いフィジカ ルフィギアを用いたコミュニケーション実習を行う ことを計画している.

\section{REFERENCES}

1) Teramachi H., Kuzuya Y., Tsuchiya T., Jpn. J. Pharm. Helth Care Sci., 34, 755-763 (2008).

2) Adachi T., Suzui M., Naoi K., Kamiya T., Hara H., Jpn. J. Pharm. Helth Care Sci., 34, 311-319 (2008).

3) Hanya M., Shibata A., Kamei H., Matsuba K., Asai M., Taniyama M., Jpn. J. Pharm. Helth Care Sci., 33, 693-701 (2007).

4) Tokunaga J., Takamura T., Ogata K., Yoshida H., Furuya Y., Totoribe K., Nagata M., Hidaka M., Matsuoka T., Ono S., Yamamoto R., Arimori K., Jpn. J. Pharm. Helth Care Sci., 34, 847-852 (2008).

5) Nihon Byoin Yakuzaishi kai, "Chukan hokoku: Yakubutsuryoho no sitsu no kojyo to anzenkakuho ni shisuru byoinyakuzaishi no atarashii gyomutenkai-Atarashii gyomutenkaizittaichosa kekka wo fumaete-," 2009.

6) Nomura T., Nikai T., Kushizaki H., Ishida R., Saito Y., J. Jpn. Soc. Clin. Anesth., 24, 329-334 (2004). 